Mental Health Research Institute and Department of Pathology, The University of Michigan, Ann Arbor, Michigan

\title{
An Enzyme Histochemical Study of Torpedoes and Dendritic Swellings in the Cerebellum*
}

\author{
By \\ REINHARD L. FRIEDE
}

With 5 Figures in the Text

(Received May 15, 1964)

\section{Introduction}

This paper reports on the activity of several enzymes in torpedoes and dendritic swellings of Purkinje cells as observed in eight cases of human post mortem material. It was of particular interest that the enzyme reaction in the axon swellings (CAJAL 1938), known as torpedoes, varied considerably among the cases; also, the enzyme activity in torpedoes varied independently from that in the dendritic swellings (asteroid bodies) of the same cells.

\section{Material and Methods}

The first four of our cases showed abundant dendritic swellings (asteroid bodies) in the molecular layer and numerous torpedoes in the granular layer; these were three children with infantile and juvenile amaurotic idiocy and one child with diffuse poliodystrophy. The fifth case, a 45 year old phenylpyruvic oligophrenic, showed only sparse dendritic expansions and moderately numerous torpedoes. Torpedoes, but no dendritic expansions, were seen in the other three cases which were of senile dementia.

All tissue was obtained within eight hours after death and immediately sectioned or placed in cold formalin. Thirty micra frozen sections of unfixed tissue were incubated in the substrate media for cytochrome oxidase and succinic dehydrogenase. Thirty micra frozen sections of formalin-fixed tissue were incubated in a substrate media for lactic dehydrogenase, NAD-diaphorase, alkaline phosphatase, acid phosphatase, acetyl cholineesterase and nonspecific cholinesterase. All incubations were done with constant agitation in an Eberbach water bath-shaker. Cytochrome oxidase and alkaline phosphatase incubations were at room temperature, all others were at $38^{\circ}$. Incubation times were: 16 hours for nonspecific cholinesterase, 5 hours for acetyl cholineesterase and 1 hour for the other enzymes. The sections were mounted in glycerin gel, or dehydrated and mounted in Permount. More complete details of the histochemical procedures as used in this laboratory are given elsewhere: succinic dehydrogenase, Friede, Fleming, and Kroller 1963; cytochrome oxidase, Burstone 1961; lactic dehydrogenase, Friede and Knolder 1964; cholinesterase, Frifide and Flemirge 1964; phosphomonoesterases, Friede and Kroller 1964.

\section{Results}

Dendritic swellings. The dendritic swelling in the cerebellar molecular layer showed very high activity of all of the oxidative enzymes studied (Figs. 1 and 3 ). The staining for lactic dehydrogenase was particularly helpful in this study because it demonstrated the numerous small dendrites originating from the swellings and even the finest arborizations were conspicuously outlined (Fig.2). In the three cases of amaurotic idiocy, most of the dendritic swellings

\footnotetext{
* This investigation was supported by U. S. Public Health Grant B 3250.
} 
did not contain lipid. The few lipid deposits which were observed in dendritic swellings showed no enzyme activity. In the case of the phenylpyruvic oligophrenic, there were only moderate expansions of the dendrites, some of which showed bizarre configurations, all clearly

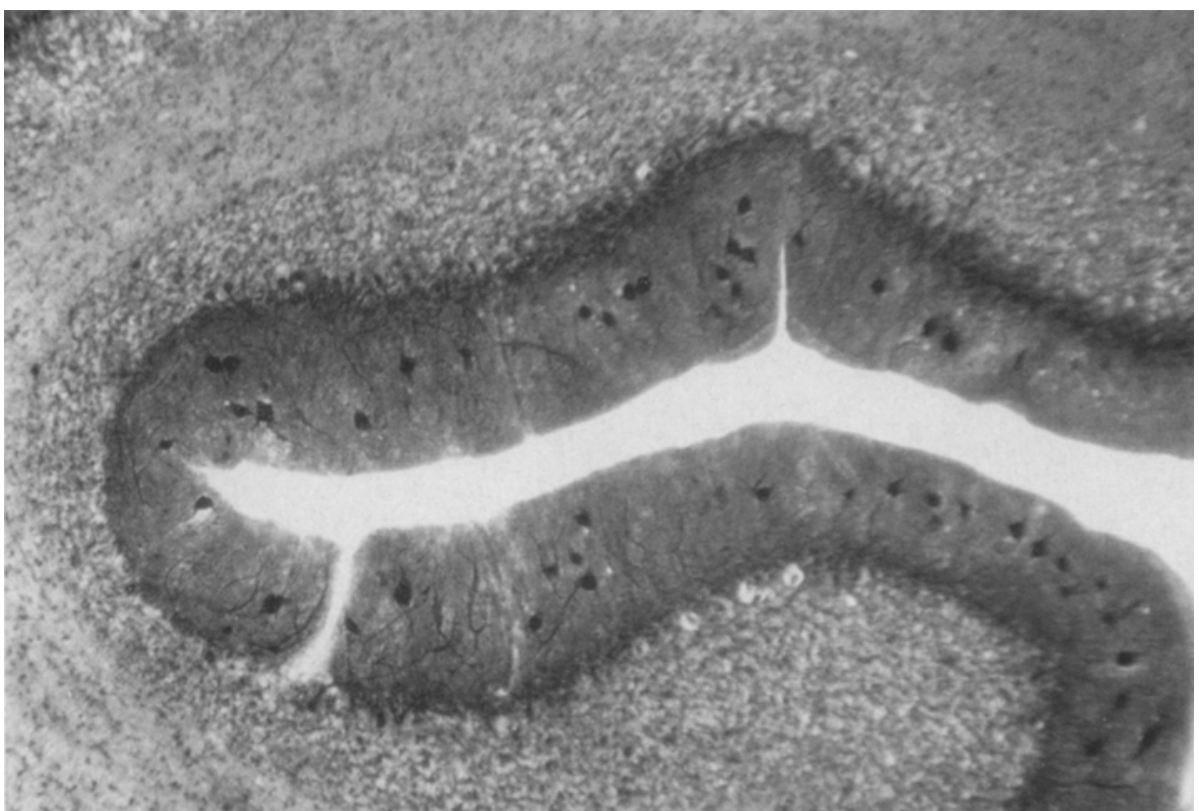

Fig. 1. Abundant swellings of Purkinje dendrites (asteroid bodies) in the cerebellar molecular layer in a case of amaurotic idiocy. Note that torpedoes are not discernible at this magnification. Lactic dehydrogenase, 30 micra, $60 \times$

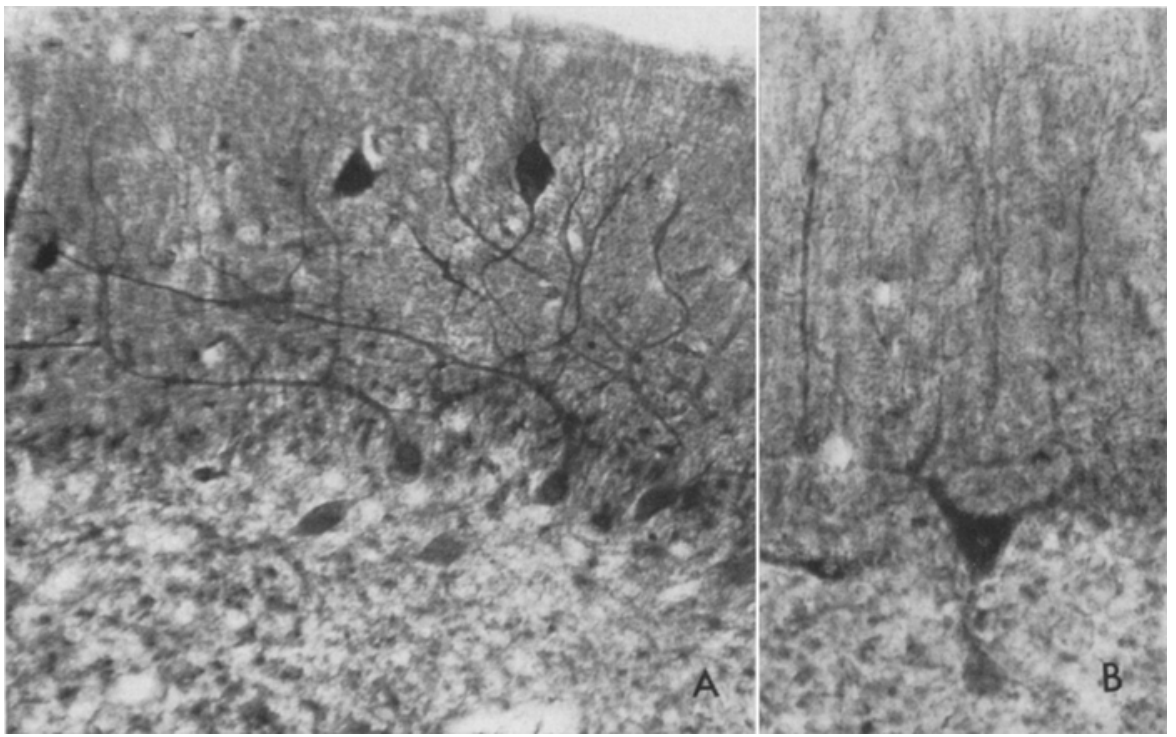

Fig. 2.A Torpedo and dendritic swellings arising from the same cell; note the marked difference of staining. The lipid deposits in the perikarya of the Purkinje cells do not stain. Amaurotic idiocy, NAD-diaphorase, 30 micra, $150 \times$; B Purkinje cell with an attached torpedo in a case of poliodystrophy; note the marked difference in enzyme activity between perikaryon and torpedo. Lactic dehydrogenase, 30 micra, $200 \times$ 
demonstrated by intense staining for oxidative enzymes. There was moderate acid phosphatase activity diffusely distributed in the dendritie swellings (Fig.4). Activity of alkaline phospha-

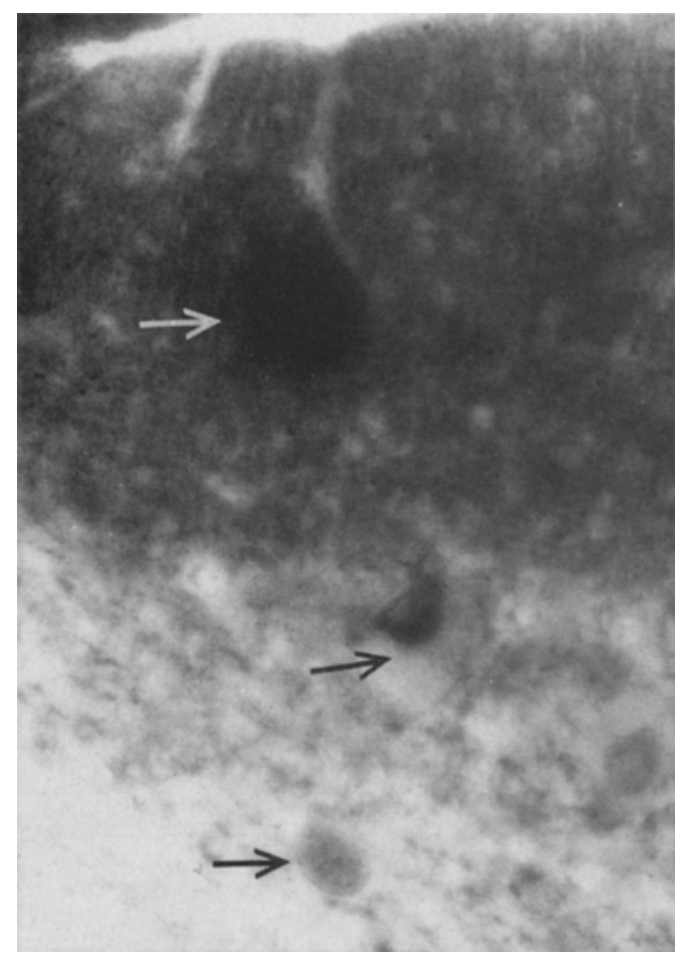

Fig. 3. Dandritic swelling (out of focus; top arrow), Purkinje cell with lipid in perikaryon (middle arrow); and torpedo (bottom arrow) show marked differences of cytochrome oxidase activity. Amaurotie idiocy. 30 micra, $300 \times$ tase, acetyl- and nonspecific cholinesterase was not discernible in the dendrites. Either these enzymes were not present or did not exceed the levels of activity in the surrounding tissue.

Torpedoes. In the cases of amaurotic idiocy and poliodystrophy the oxidative enzyme activity in torpedoes was always weak and much lower than the activity in dendritic swellings or in Purkinje cell perikarya in the same section (Fig.2). Occasionally, in the same level of focus, one could compare the enzyme activity of a perikaryon and its attached torpedo and dendritic swelling. In some torpedoes the weak oxidative enzyme activity was diffusely distributed throughout the cytoplasm, in others activity was localized only at the membrane of the torpedo. The weak staining in the torpedoes in the three cases of amaurotic idiocy was not the result of displacement of cytoplasm by lipid storage, as shown by counterstained sections. There was moderate acid phosphatase activity in the torpedoes, similar to that observed in the dendritic swellings Fig.4). In the other four cases, torpedoes consistently had a very intense staining for oxidative enzymes,

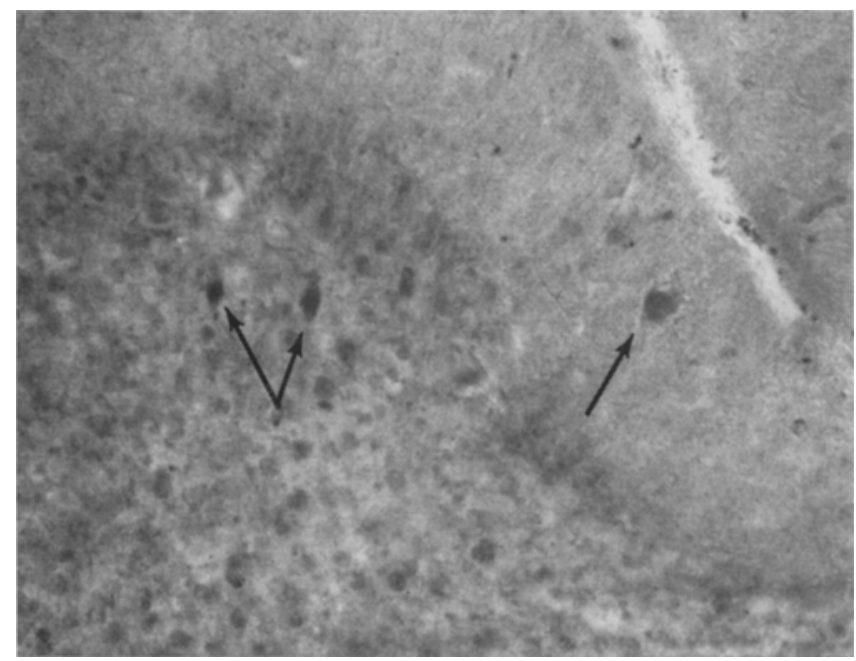

Fig. 4. Acid phosphatase staining is nearly equal in torpedoes (left arrows) and dendritic swellings, (right arrow). Simultaneous coupling method, 30 micra, $110 \times$ 
comparable to that in Purkinje cell perikarya (Fig.5). However, they were not discernible by the reaction for acid phosphatase. Alkaline phosphatase, acetyl- and nonspecific cholinesterase activity was never observed in torpedoes.

\section{Discussion}

Torpedoes and dendritic swellings are characteristic but nonspecific injury responses in Purkinje cell processes (CAJAL 1938). They are particularly prevalent in congenital cerebellar atrophies, but torpedoes are also known to develop following nonspecific damage in adult brain (ScharenBerG 1953). Metallic impregnation has been the classical method of demonstrating the morphology of these changes. The present histochemical studies have demonstrated that dendritic swellings show consistently intense staining for oxidative enzymes, moderate staining for acid phosphatase, and no demonstrable activity of alkaline phosphatase, acetyl- and nonspecific cholinesterase. The strong reaction for oxidative enzymes in swollen dendrites suggests that dendritic expansions do not merely represent a local edema or an accumulation of inert material.

In contrast, it was indeed surprising to learn that torpedoes differed quite markedly among cases in their supply of oxidative enzymes. In four cases, the torpedoes showed weak activity, while four other cases showed consistently intense staining of torpedoes. The intense staining in the torpedoes compares well with high levels of oxidative enzyme activity and numerous mitochondria (DE WEBSTER 1962) that have been demonstrat-

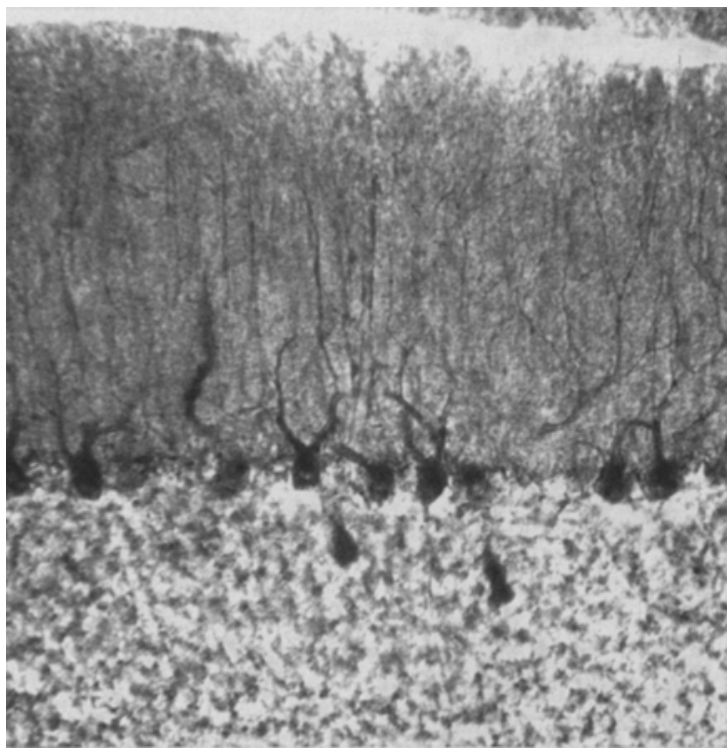

Fig. 5. Two torpedoes in a case of senile dementia exhibit intense staining as compared with the perikarya of Purkinje cells. Lactic dehydrogenase, 30 micra, $110 \times$

ed in axon swellings in transected central fiber tracts or peripheral nerves (FRIEDE 1959, 1964; KREUTZBERG and WECHSLER 1963) or in human neuropathological material, e.g., near arteriosclerotic infarcts (FRIEDE 1962). Such swellings were usually devoid of acid phosphatase.

At present, one can only speculate as to the causes of the variable enzyme activity in torpedoes. It is unlikely that the low activity in torpedoes was related to the length of the time after onset of injury because dendritic swellings of the same cells had an intense activity. Another possible correlation might be considered: all four cases with weak oxidative enzyme activity in torpedoes were children debilitated for most of their lives, while the other four cases were adults, whothough demented - were not incapacitated. It is not known, at this time, whether axonal swellings of immature or inactive axons differ from those of mature ones. 


\section{Summary}

In 8 cases, the following enzymes were studied in the dendritic swellings and torpedoes of Purkinje cells of cerebellum: succinic dehydrogenase, cytochrome oxidase, lactic dehydrogenase, NAD-diaphorase, alkaline phosphatase, acid phosphatase, acetyl cholinesterase and nonspecific cholinesterase. Activity of the oxidative enzymes was always extremely high in the dendritic swellings, but varied greatly among cases in the torpedoes; 4 cases showed very weak activity of oxidative enzymes in torpedoes, while 4 other cases showed an intense reaction. Dendritic swellings and torpedoes exhibited no alkaline phosphatase, acetyl cholinesterase, or nonspecific cholinesterase activity.

\section{Zusammenfassung}

In. Dendritenanschwellungen und Torpedos der Purkinje-Zellen des Kleinhirns von 8 Fällen wurden die folgenden Enzyme untersucht: BernsteinsäureDehydrogenase, Cytochrom-Oxidase, Milchsäure-Dehydrogenase, NAD-Diaphorase, alkalische Phosphatase, saure Phosphatase, Acetylcholinesterase und unspezifische Cholinesterase. Die Aktivität der oxidativen Enzyme war in den Dendritenanschwellungen immer sehr hoch, in den Torpedos aber von Fall zu Fall sehr unterschiedlich: 4 Fälle zeigten nur sehr geringe Aktivität, die 4 anderen jedoch eine sehr intensive Reaktion. Die Dendritenanschwellungen und Torpedos zeigten keine Aktivität der alkalischen Phosphatase, Acetylcholinesterase oder unspezifischen Cholinesterase.

\section{Bibliography}

Burstone, M. S.: Modifications of histochemical techniques for the demonstration of cytochrome oxidase. J. Histochem. Cytochem. 9, 59-65 (1961).

CAJAL, S. R.: Degeneration and Regeneration of the Nervous System, R. M. MaY, ed., Vol.I. New York: Hafner Publishing Co. 1959.

Frifde, R. L.: Transport of oxidative enzymes in nerve fibers. A histochemical investigation of the regenerative cycle in neurons. Exp. Neurol. 1, 441-466 (1959).

- An enzyme histochemical study of cerebral arteriosclerosis. (With some data on the pathogenesis of periarterial scars.) Acta neuropath. (Berl.) 2, 58-72 (1962).

- Axon swellings produced in vivo in isolated segments of nerves. Acta neuropath. (Berl.) $\mathbf{3}$, $229-237$ (1964).

-, and L. M. FLevirg: A comparison of cholinesterase distribution in the cerebellum of several species. J. Neurochem. 11, 1-7 (1964).

- -, and M. KNOLLER: A quantitative appraisal of enzyme histochemical methods in brain tissue. J. Histochem. Cytochem. 11, 232-245 (1963).

-, and M. KrolteR: Lactate dehydrogenase isoenzymes in transected nerves. J. Neurochem. 11, 537-540 (1964).

- - A quantitative appraisal of histochemical methods for phosphomonoesterases in brain tissue (in preparation).

KreutzBERG, G.: Lokalisierter Oxydoreduktaseanstieg bei der Wallerschen Degeneration des peripheren Nerven. Naturwissenschaften 50, 96 (1963).

- , u. W. WhohsLer: Histochemische Untersuchungen oxydativer Enzyme am regenerierenden Nervus ischiadicus der Ratte. Acta neuropath. (Berl.) 2, 349-361 (1963).

ScharmNBERG, K.: Atrophy of the cerebellum following pressure. J. neuropath. exp. Neurol. 12, 11-23 (1953).

WeBsTER, H. F., DE: Transient, focal accumulation of axonal mitochondria during the early stages of Wallerian degeneration. J. Cell Biol. 12, 361-383 (1962).

Dr. R. L. FrIede,

University of Michigan, Ann Arbor, Mental Health Research Institute 